THE secretory leukocyte protease inhibitor (SLPI) is a low-molecular-weight in hibitor of proteases, such as elastase and cathepsin G which are released from leukocytes during phagocytosis. The purpose of this study was to determine whether or not SLPI is able to in hibit IgE-mediated histamine release. Nasal mucosa from 11 test subjects without atopic disposition was used for this in vitro study. We found that SLPI inhibited histamine release in a dose-dependent way but was without influence on the spontaneous release.

Key words: SLPI, IgE, chymase, histamine, nasal mucosa

\section{IgE-mediated histamine release from nasal mucosa is inhibited by SLPI (secretory leukocyte protease inhibitor) to the level of spontaneous release}

\author{
U. Westin, ${ }^{1}$ E. Lundberg ${ }^{2}$ and K. Ohlsson ${ }^{2, C A}$
}

${ }^{1}$ Department of Otolaryngology and Head and Neck Surgery, and ${ }^{2}$ Department of Surgical

Pathophysiology, University Hospital of Malmö,

University of Lund, SE-205 02 Malmö, Sweden

${ }^{\mathrm{CA}}$ Corresponding Author

\section{Introduction}

Secretory leukocyte protease inhibitor (SLPI) is a nonglycosylated, acid-stable, neutral serine antiprotease first described by Haendle et al. in 1965. ${ }^{1}$ Isolation of native inhibitor (SLPI) from parotide juice allowed the determination of its amino acid sequence. ${ }^{2}$ SLPI is an important regulator of proteases such as granulocyte elastase and cathepsin G. It prevents these enzymes from inhibiting the mucociliary activity in the airways during purulent infection. ${ }^{3-7}$ It is found in great amounts in nasal secretion and is thought to be the major inhibitor of granulocyte elastase in these secretions, while $\alpha 1$-PI plays a minor role. ${ }^{8,9}$

Mast cells initiate hypersensitive reactions by binding $\operatorname{IgE}$ to high-affinity receptors within the cell membrane in response to allergen challenge. This response causes a rapid release of several mediators, such as histamine and proteases. ${ }^{10,11}$ SLPI has been found to inhibit one of these enzymes, namely chymase. $^{12,13}$ It has been found to be the fastest reacting chymase inhibitor compared with plasma inhibitors such as $\alpha 1$-PI and $\alpha 1$-antichymotrypsin. ${ }^{14}$ Chymase is thought to play an important role in IgEmediated histamine release by causing mast cell degranulation. ${ }^{15-17}$ Inhibitors of chymase have been shown to inhibit IgE-mediated histamine release from isolated mast cells, probably after incorporation into mast cell granules. This implies that chymase may play a role in the stimulation of the IgE-mediated activation/secretion response. ${ }^{18,19}$ It has also been demon- strated that SLPI increases in nasal secretion when patients with atopic disposition are exposed to allergen and histamine. ${ }^{20}$ Neutral serine proteases such as granulocyte elastase, cathepsin $\mathrm{G}$ and mast cell chymase are potent secretagogues for airway gland serous cells. Histamine also degranulates serous cells, but is not such a potent secretagogue as these proteases. ${ }^{21-23}$

The purpose of this study is to report the the effect of SLPI on IgE-mediated histamine release from nasal mucosa in vitro. Another objective was to examine whether IgE-stimulation of nasal mucosa caused an increase in SLPI secretion.

\section{Materials and Methods}

Nasal mucosa was obtained from 11 patients undergoing conchotomi of the inferior turbinate due to nasal congestion. They were otherwise healthy patients with no known atopic predisposition. After, surgery the mucosa was immediately transported to the laboratory in a sterile test tube. The mucosa from each patient was then separated from the osseous part and divided into five equally sized pieces with a scalpel. Each piece was weighed and put into a sterile test tube containing Earle's M-199 salt, (GIBCO BRL, Life Technology, Täby, Sweden). To stimulate antigen cross-linking of membrane bound $\mathrm{IgE}$ and histamine release we used anti-IgE (DAKO, Glostrup, Denmark). ${ }^{10}$ RhSLPI was obtained from Synergen Inc, Boulder, CO, USA. 


\section{Assay of inhibition of histamine release}

The tissue samples from each patients were preincubated in $2 \mathrm{ml}$ of the medium for $15 \mathrm{~min}$ at $37^{\circ} \mathrm{C}$. After preincubation a final concentration of $0,7.5$, $150 \mu \mathrm{M}$ rhSLPI were added to three different test tubes and incubated for $15 \mathrm{~min}$ at $37^{\circ} \mathrm{C}$. Then $15 \mu \mathrm{l}$ anti-IgE, $15 \mathrm{~g} / \mathrm{l}$, were added to these three test tubes. Inhibition of spontaneous histamine release was measured by incubating one tissue sample with the final concentration of $150 \mu \mathrm{M}$ rhSLPI without any anti-IgE-stimulation. One test tube tissue was incubated with medium only. Incubation continued at $37^{\circ} \mathrm{C}$. Samples of $200 \mu \mathrm{l}$ were taken from each of the five test tube supernatants before $(0 \mathrm{~min}), 15 \mathrm{~min}$ after adding rhSLPI and then the following 30, 45, 75 and $135 \mathrm{~min}$.

Histamine release was measured with a commercial radioimmunoassay (RIA)-kit (Immunotech, KEMILA, Sollentuna, Sweden). The RIAtkit was able to detect non-methylated histamine. Briefly, the RIA was performed as follows: step 1, acetylation of standard solution or sample; step 2, $50 \mu \mathrm{l}$ acetylated standard or sample and $500 \mu \mathrm{l}$ tracer was added into antibody coated tubes and were then incubated for $18 \mathrm{~h}$ at $2-6^{\circ} \mathrm{C}$; step 3 , the coated tubes were aspirated and the total counts per minutes and bound counts per minutes were registered. Histamine release was expressed as the percentage increase or decrease relative to the sample taken before anti-IgE-stimulation and after incubation with rhSLPI.

\section{Assay of SLPI}

Tissue samples from six subjects were treated as previously described. They were preincubated in $2 \mathrm{ml}$ Earle's M-199 salt, for $15 \mathrm{~min}$ at $37^{\circ} \mathrm{C}$. A medium sample of $200 \mu \mathrm{l}$ was removed from each test tube. One tissue sample was incubated in medium only while the other was stimulated with anti-IgE. Then $200 \mu \mathrm{l}$ medium were collected from each test tube at 30, 45, 75 and $135 \mathrm{~min}$ after anti-IgE stimulation. SLPI was measured with non-competitive ELISA, as described earlier by Bergenfeldt and Ohlsson. ${ }^{24}$ Monoclonal mouse-antibodies against SLPI (produced at our laboratory) were made to adhere to wells of microtitre plates.

Diluted samples and standard were then added. An anti-SLPI sheep IgG-antiserum (produced at our laboratory) was then added. Finally, a rabbit anti-sheep IgG antibody, conjugated with alkaline phosphatase (Dakopatt AS, Copenhagen, Denmark), was added.

Alkaline phosphatase cleaved the substrate (4-paranitro-phenyl-phosphate). The substrate was quantified at $405 \mathrm{~nm}$ in an automatic Titertec multiscan photometer. To verify the effect of anti-IgE we measured the histamine release as described above. SLPI was expressed as the percentage increase compared with the sample taken before stimulation with anti-IgE.

\section{Statistics}

Regression coefficients were calculated for each histamine release curve from each one of the experiments. The hypothesis, i.e. the differences in regression coefficient were tested with a non-parametric Wilcoxon's paired rank sum test. ${ }^{25}$

The Man-Whitney $U$-test was calculated on the results at 30, 45, 75 and $135 \mathrm{~min}$ in order to see if there was a significant increase in SLPI due to IgEstimulation.

\section{Results}

When nasal mucosa from 11 subjects were preincubated with SLPI, IgE-mediated histamine release was inhibited in a dose-dependent manner. There was significant inhibition $(P=0.028$ and $P=0.015)$ of histamine release at SLPI concentrations of $7.5 \mu \mathrm{M}$ and $150 \mu \mathrm{M}$. Inhibition was observed after $30 \mathrm{~min}$ incubation (Fig. 1). RhSLPI inhibited IgE-mediated histamine release to the level of spontaneous histamine release (Fig. 2), but did not affect histamine release in the absence of $\operatorname{IgE}$ stimulation (Fig. 3).

Pronounced IgE-mediated histamine release was observed in the absence of added rhSLPI $(P=0.0093)$ compared with spontaneous histamine release (Fig. 4).

The effect of IgE on nasal mucosal secretion of SLPI was also studied (six subjects). No significant increase in SLPI was observed when nasal mucosa was subjected to $\operatorname{IgE}$ stimulation in vitro.

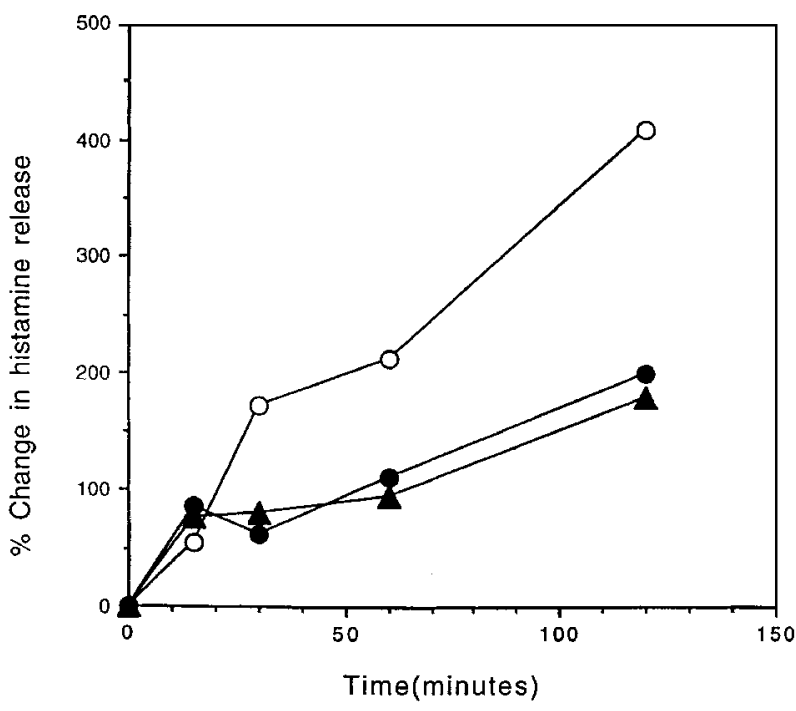

FIG. 1. IgE-mediated histamine release in nasal mucosa at various concentrations, $0 \mu \mathrm{M}(-\circ), 7.5 \mu \mathrm{M}(-\bullet-), 150 \mu \mathrm{M}$ $(-\boldsymbol{\Lambda}-)$ SLPI. There was a significant inhibition $(P=0.028$ and $P$ $=0.015$ ) of histamine release at $7.5 \mu \mathrm{M}$ and $150 \mu \mathrm{M}$. Statistics are calculated on the regression coefficient from the results of the 11 subjects. This figure shows results from a representative experiment. 


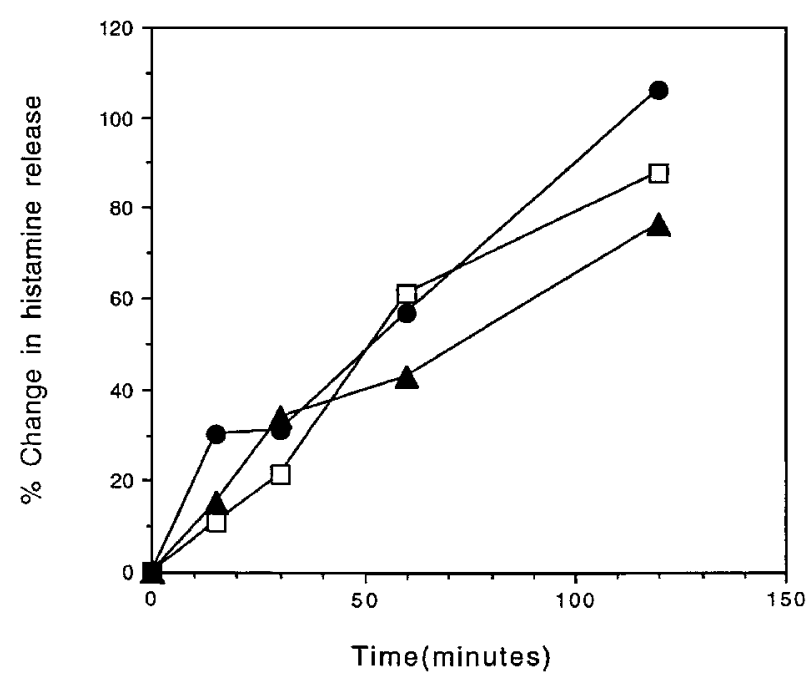

FIG. 2. IgE-mediated histamine release in nasal mucosa at various concentration, $7.5 \mu \mathrm{M}(-\bullet)$ and $150 \mu \mathrm{M},(-\mathbf{-})$ of SLPI compared with spontaneously released histamine $(---)$. SLPI had no influence on spontaneous histamine release.

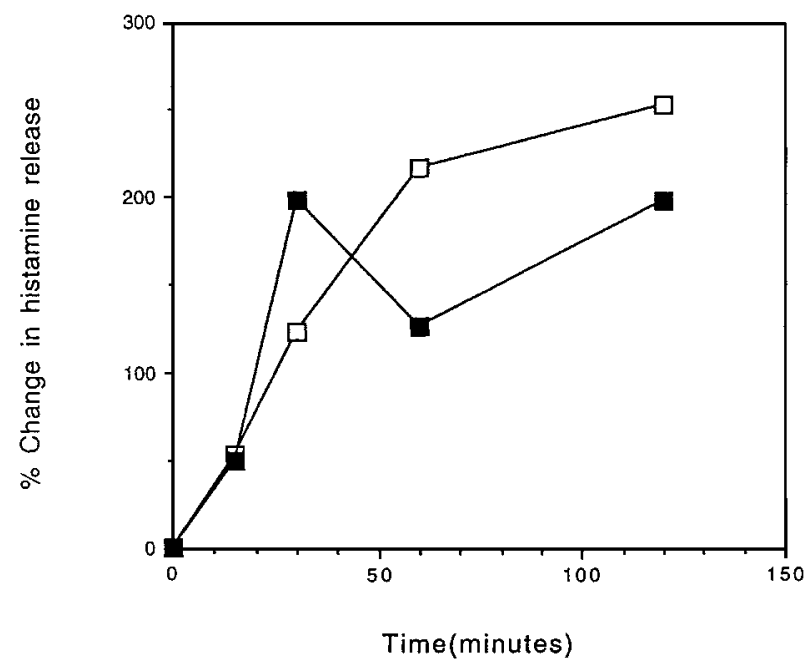

FIG. 3. Spontaneously released histamine in nasal mucosa incubated with SLPI, $150 \mu \mathrm{M},(--)$ compared with spontaneously released histamine in the absence of SLPI (- - ). No significant inhibition of histamine release was seen in the absence of IgE-stimulation.

\section{Discussion}

Recent studies indicate that SLPI probably plays a role as a regulator in IgE-mediated reactions, perhaps by inhibiting chymase activity. ${ }^{12,13}$ Chymase is a serine protease which resides in mast cell granules. ${ }^{16,26,27}$ Mast cell degranulation is most likely caused by chymase, thus inducing histamine release. ${ }^{15,17-19}$ We have shown that SLPI inhibits IgE-mediated histamine release in a dose-dependent manner in explanted human nasal mucosa (Fig. 1). SLPI inhibits histamine release to the level of spontaneous release (Fig. 2). These results support the suggestion that SLPI may be an important participant in allergic reactions. The

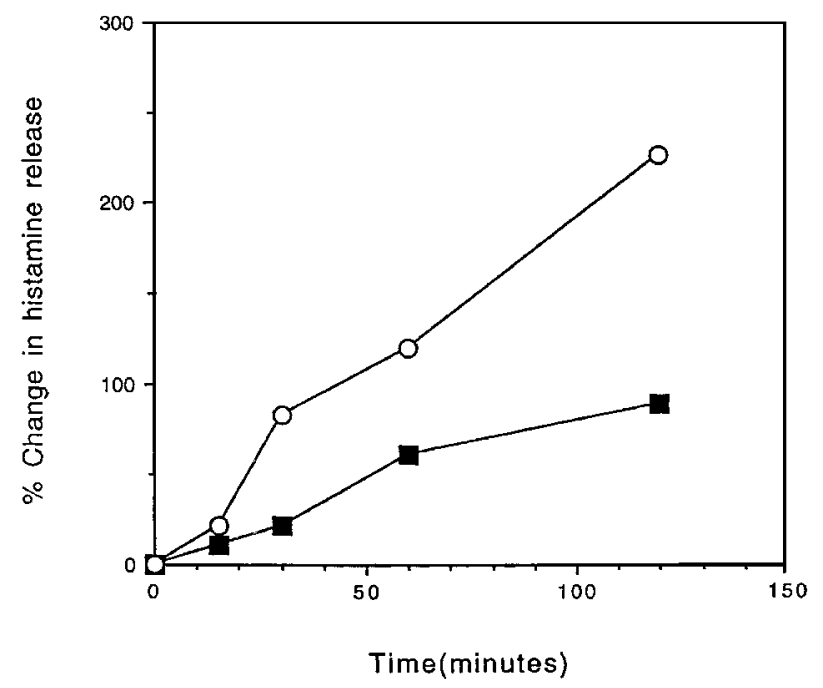

FIG. 4. Anti-lgE induced histamine release in nasal mucosa $(-)$ compared with spontaneous release $(--)$. This figure demonstrates the effect of $\lg E$ on histamine release in nasal mucosa.

findings of Dietze et al. ${ }^{12}$ suggest that preincubating tonsilar mast cells with r-MPI (SLPI) for $30 \mathrm{~min}$ had no effect, while incubation for $120 \mathrm{~min}$ restricted histamine release to the level of spontaneous release. Their study indicated that the inhibitor may not have an impact on immediate hypersensitive reactions, but is of greater importance to prolonged allergen exposure. By incubating human nasal mucosa with SLPI, we found pronounced inhibition of histamine release after $30 \mathrm{~min}$, supporting the importance of SLPI as a regulator in immediate hypersensitive reactions. Whether or not SLPI forms complexes with chymase intra- or extracellularly is not known. Antibodies of chymase are incorporated into mast cell granules and inhibit histamine release, as shown by Kido et al. ${ }^{18}$ However, mast cells granules contain SLPI, ${ }^{28}$ which may indicate that the inhibitor is able to penetrate the cell membrane and act as a regulator inside the cell. It has been show $\mathrm{n}$ that SLPI increases in nasal secretion in allergic subjects when they are exposed to allergens. ${ }^{20}$ Serine proteases such as elastase, cathepsin $\mathrm{G}$ and chymase are potent secretagogues for airway gland serous cells. ${ }^{21-24}$ We proposed that chymase may also stimulate the secretion of SLPI. By incubating nasal mucosa with anti-IgE, mast cell chymase is activated and may be able to stimulate the serous cells of nasal mucosa. No significant increase in SLPI secretion could be seen, which may suggest that a nervous component is required to increase secretion in response to this kind of stimulation. In conclusion, our results obtained from experiments with intact human nasal mucosa, support the theories that SLPI plays a role in type 1 reactions by inhibiting histamine release, and that IgE does not affect SLPI secretion in nasal mucosa ex vivo. 


\section{References}

1. Haendle H, Fritz H, Trautschold I, Werle E Über einen hormonhängigen Inhibitor für proteolytische Enzyme in menchlichen accesorischen Gesschlechtrüsen und im Sperma. Hoppe-Seyler's Physiol Chem 1965; 434: $185-188$.

2. Thomson RC, Ohlsson K. Isolation properties and complete amino acid sequence of human secretory protease inhibitor, a potent inhibitor of leucocyte elastase. Proc Natl Acad Sci USA 1986; 83: 6692-6696.

3. Hochstrasser K, Reichert R, Schwartz S, Werle E. Isolerung und Charakteriserung eines Proteasen Inhibitors aus menchlichen bronkial Sekret. Hoppe-Seyler's Z Physiol Chem 1972; 353: 221.

4. Ohlsson K, Tegner H. Granulocyte collagenase, elastase and plasma protease inhibitor in purulent sputum. Eur Clin Invest 1975; 5: 221-227.

5. Ohlsson K, Tegner $\mathrm{H}$ Inhibition of elastase from granulocytes by the low molecular weight bronchial protease inhibitor. Scand J Cin Lab Invest 1976; 36: 437-445.

6. Tegner H, Ohlsson K, Toremalm NG, Mecklenburg CV. Effects of human leukocyte enzymes on tracheal mucosa and its mucociliary activity. Rhinology 1979; 17: 199-206.

7. Seemüller U, Arnold M, Fritz $\mathrm{H}$, et al. The acidstable proteinase inhibitor of human mucous secretions (HUSI-I, antileucoprotease). FEBS Lett 1986; 199: 43-48.

8. Fryksmark U. Jannert M, Ohlsson K, Whil J-A, Tegner H Secretory leukocyte protease inhibitor in normal, allergic and virus induced nasal secretions. Rhino logy 1989; 27: 97-103.

9. Westin U, Fryksmark U, Polling $\AA$, Ohlsson K. Localisation of secretory leukocyte proteinase inhibitor mRNA in nasal mucosa. Acta Otolaryngol 1994; 114: 199-202.

10. Igarashi Y, Kurosawa O, Ishikawa Y, Myachi H, et al. Characteristics of histamine release from cultured human mast cells. Clin Exp Allergy 1996; 26: 597-602.

11. Wasserman SI. Mediators of immediate hypersensitivity. J Allergy Clin 1983; 72: 101-113.

12. Dietze SC, Sommerhoff ChP, Fritz H. Inhibition of histamine release from human mast cells ex vivo by natural and syntheic chymase inhibitors. Biol Chem Hoppe-Seyler 1990; 371: 75-79.

13. Fink E, Nettelbeck R, Fritz H. Inhibition of mast cell chymase by eglin c and antileucoprotease (HUSI-I). Biol Chem Hoppe-Seyler 1990; 371: 75-79.

14. Walter M, Plotnik M, Schechter NM Inhibition of human mast cell chymase by secretory leucocyte proteinase inhibitor: enhancement of the interaction by heparin. Arch Biochem Biophys 1996; 327: 81-88.

15. Schick B, Austen KF, Schwartz LB. Activation of rat serosal mast cells by chymase, an endogenous secretory granule protease. J Immunol 1984; 135: 2571-2577.

16. Okuno-Kaneda S, Saito T, Kawasaki Y, Ischkawa A, Tomita K. Properies of proteases in mast cell granules. Biochem Pharmac 1980; 29: $1715-1722$.
17. Hultsch T, Ennis M, Heidtmann $\mathrm{HH}$. The role of chymase in ionophoreinduced histamine release from human pulmonary mast cells. Advances in experimental medicine and biology. Plenum Press 1988; 240: 133-136.

18. Kido H, Fukusen N, Katuma N. Antibodies and inhibitors of chymase are incorporated into mast cell granules and inhibit histamine release. Biol Chem Hoppe-Seyler 1988; 369: 95-100.

19. Kido H, Fukusen N, Katuma N. Antibody and inhibitor of chymase inhibit histamine release in immunoglobulin E-activated mast cells. Biochem Int 1985; 10: 863-871.

20. Hee Lee Ch, Igarashi Y, Hohman RJ, Kaulbach H, White MV, Kaliner MA. Distribution of secretory le ucoprotease inhibitor in human nasal airway. Am Rev Respir Dis 1993; 147: 710-716.

21. Sommerhoff CP, Caughey GH, Finkbeiner WE, Lazarus SC, Basbaum CB, Nadel JA. Mast cell chymase a potent secretagogue for airway gland serous cells. J Im munol 1989; 142: 2450-2456.

22. Sommerhoff CP, Fang KC, Nadel JA, Caughey $\mathrm{H}$ Classical second messenger are not involved in proteinase-induced degranulation of airway gland cells. Am J Physiol 1996; 271: 796-803.

23. Sommerhoff CP, Nadel JP, Basbaum CB, Caughey H. Neutrophil elastase and cathepsin $\mathrm{G}$ stimulate secretion from cultured bovine airway gland serous cells. J Clin Invest 1990; 85: 682-689.

24. Bergenfeldt M, Ohlsson K. Protease-antiprotease levels and whole-blood chemiluminiscence in acute peritonitis. Gastroent Japon 1993; 28: 687-698.

25. Matthews JNS, Altman DG, Cambell MJ, Royston P. Analysis of serial measurements in medical research. Br Med J 1990; 300: 230-235.

26. Irani A-MA, Schwartz LB. Human mast cell heterogenety. Allergy Proc 1994; 15: 303-308.

27. Irani A-MA, Bradford TR, Kepley ChL Schechter NM, Schwartz LB. Detection of MCT and MCTC types of human mast cells by immunohistochemistry using new monoclonal anti-trypsin and anti-chymase antibodies. J Histochem Cytochem 1989; 37: 1509-1515.

28. Westin U, Polling $\AA$, Ohlsson K. Human mast cells contain SLPI (secretory leukocyte proteinase inhibitor): demonstrated by immunohistochemistry and in situ hybridisation. Submitted.

ACKNOWLEDGEMENTS. This study was supported by grants from: The Swedish Medical Research Council (3910), the Foundations of Alfred Osterlund and Johan and Greta Koch, the Medical Research Foundations of the University Hospital Malmö and the Medical Faculty, Lund University. Statistical guidance by medical statistician Jan-Åke Nilsson, University Hospital Malmö.

\section{Received 19 January 1998; accepted in revised form 16 March 1998}




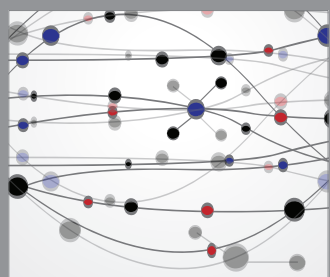

The Scientific World Journal
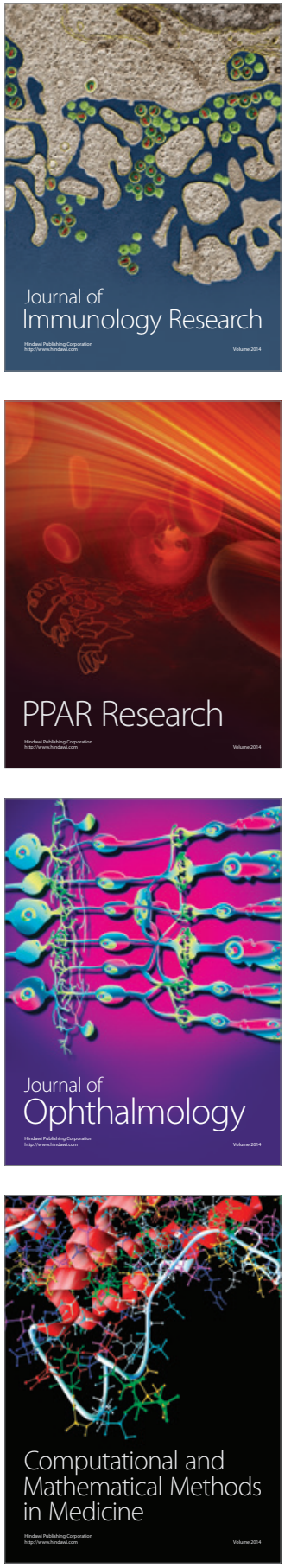

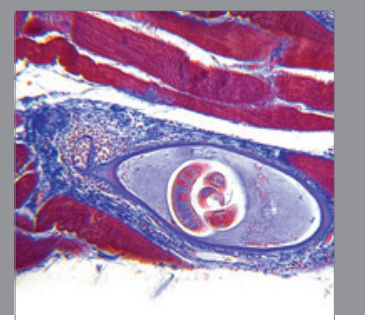

Gastroenterology

Research and Practice
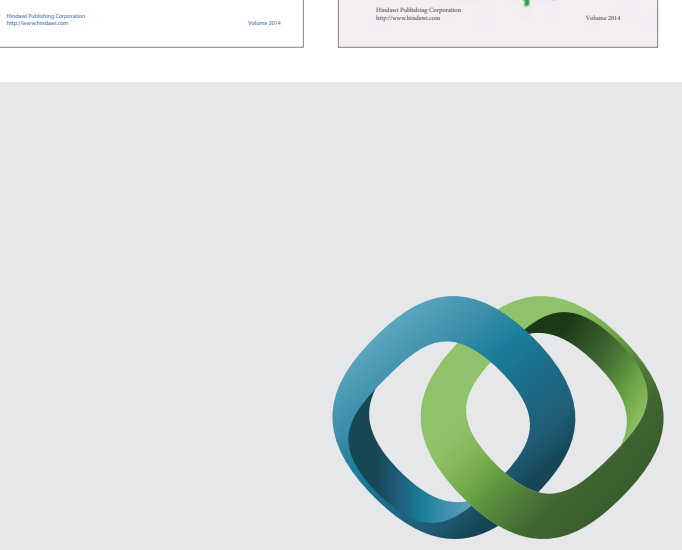

\section{Hindawi}

Submit your manuscripts at

http://www.hindawi.com
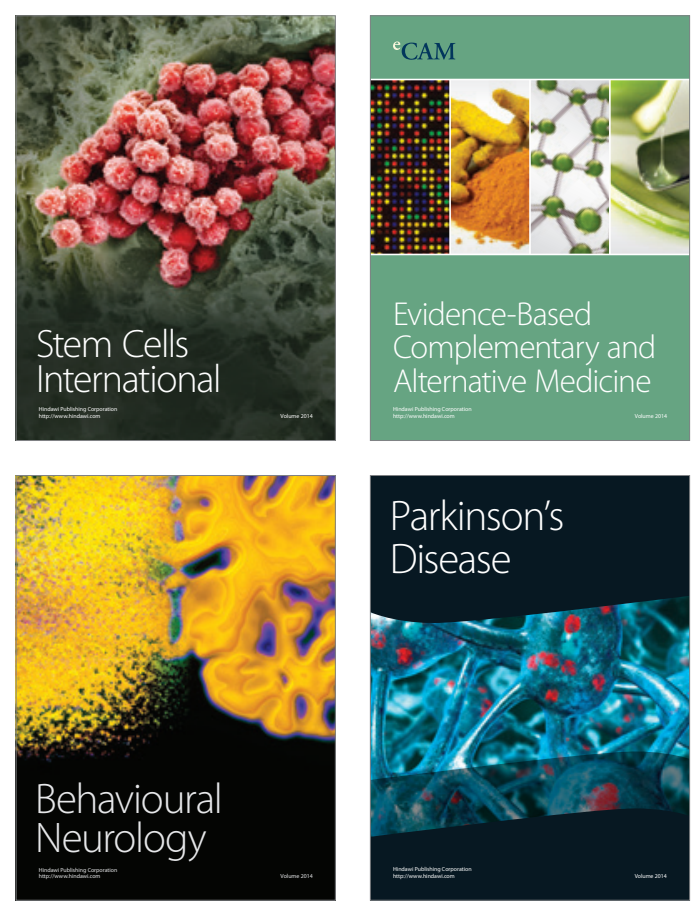

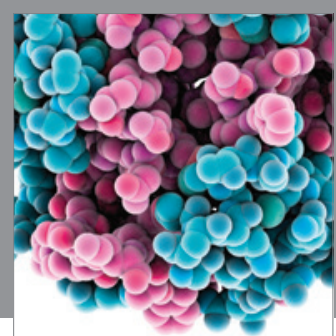

Journal of
Diabetes Research

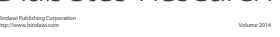

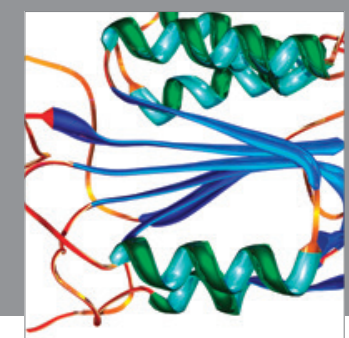

Disease Markers
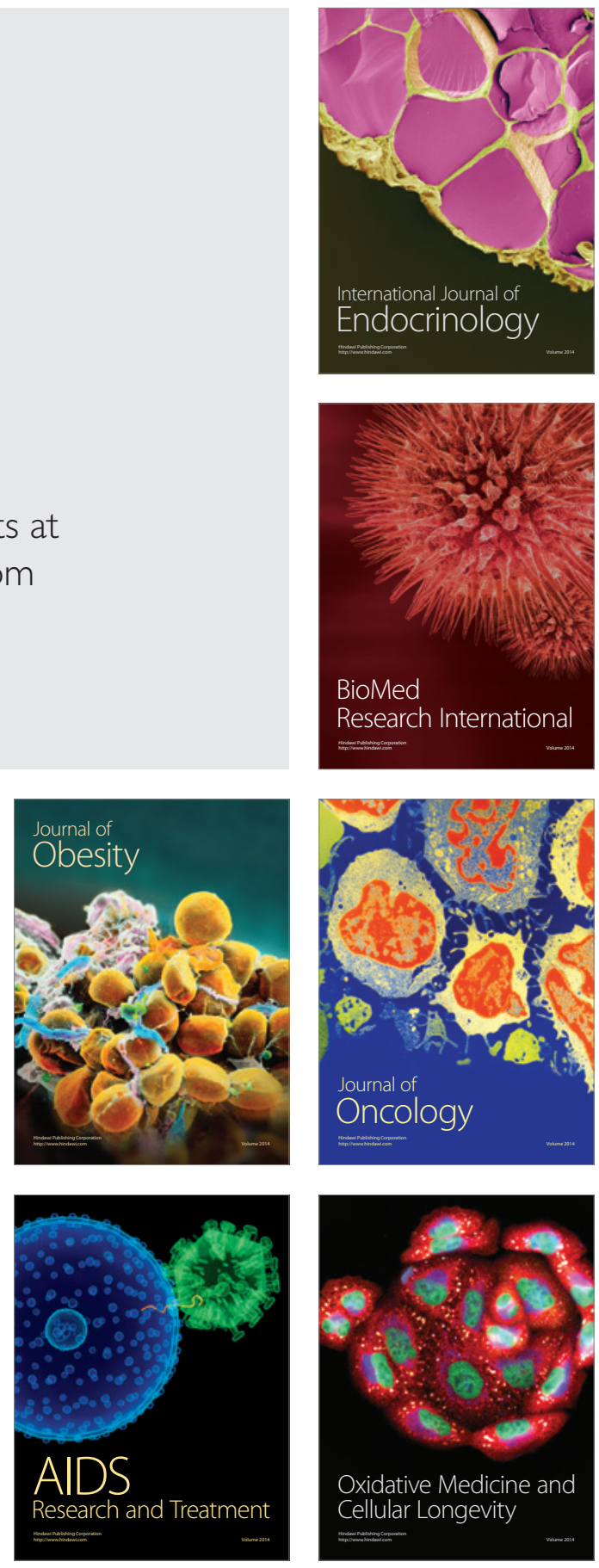